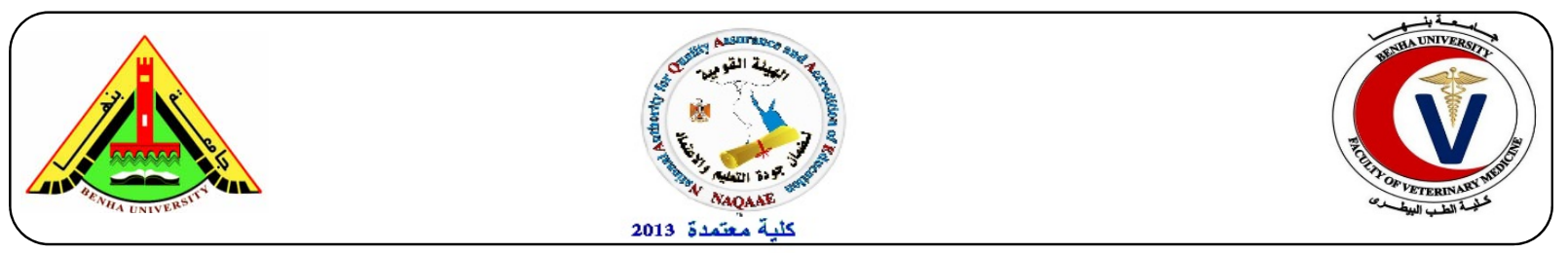

\title{
Incidence of $E$. coli and Salmonellae in ready to eat fast foods
}

\author{
Fahim Aziz Eldin Shaltout ${ }^{1}$; Mohammed Farouk ${ }^{2}$; Hosam A.A. Ibrahim ${ }^{3}$ and Mostafa E.M. Afifi ${ }^{4}$ \\ ${ }^{1}$ Food Control Department, Faculty of Veterinary Med., Banha University, Egypt. \\ ${ }^{2}$ Food Hygiene Dept., Eldoki Lab., Animal Health Research Institute \\ ${ }^{3}$ Food Hygiene Dept., Faculty of Veterinary Med., Alexandria University and \\ ${ }^{4}$ Veterinary Hospital Faculty of Veterinary Med., Banha University.
}

\section{A B S T R A C T}

A total of 100 random samples of ready- to - eat sandwiches of beef products represented by kofta, liver, shawerma and sausage products (25 samples of each) were collected from different fast food services in different districts at kaliobia Governorate to be examined bacteriologically for detection of Salmonellae and Escherichia coli. The perecentages of Salmonellae in the examined samples of kofta, liver, shawerma and sausage products were $32 \%, 60 \%, 8 \%$ and $40 \%$, respectively. The obtained results indicated that the incidence of E. coli was $20 \%, 8 \%$ and $32 \%$ and $40 \%$ in the examined kofta, shawerma, sausage and liver samples, respectively.

KEY WORDS: ready- to - eat sandwiches, E. coli, Salmonellae, kofta, liver, shawerma, sausage.

(http://www.bvmj.bu.edu.eg)

(BVMJ-32(1):18 -22, 2017)

\section{INTRODUCTION}

Ready - to - eat meat (RTE) products are highly demanded due to their high biological value, reasonable price, agreeable taste and easily serving, as well as excellent sources of high quality protein, minerals and vitamins (Mosupy et al., 1998; World Health Organization "WHO", 1984). Also, RTE foods reflect consumer demand for convenient foods, consumer is looking for RTE foods that are fresh, healthy, safe, additive free and nutritious (Fang, 2005). Salmonellosis is a worldwide problem responsible for food poisoning outbreaks in human beings without indication of decline despite the traditional food hygiene efforts. In Egypt, several food poisoning outbreaks were reported due to consumption of meat and meat products contaminated with different strains of Salmonella organisms (Varnam and Evans, 1991). Therefore, the current study was applied to evaluate the bacteriological status of some ready to eat meat meals sold at different districts and restaurants in Benha city, Kaliobia Governorate.

\section{MATERIAL AND METHODS}

\subsection{Collection of samples}

A total of 100 random samples of ready to eat beef kofta, beef liver, shawerma and beef sausage ( 25 of each) were collected from different districts and restaurants in Benha city Kaliobia Governorate to be evaluated microbiologically. Each sample was kept in a separate sterile plastic bag and put in an ice box then transferred to the laboratory under complete aseptic conditions without undue delay and examined bacteriologically to evaluate the hygienic health hazard of contaminated with some food borne pathogens.

\subsection{Bacteriological examination}

\subsubsection{Preparation of samples (American Public Health Association (APHA), 1992).}

To 25 grams of the samples under examination were taken under aseptic condition to sterile Stomacher bag then add $225 \mathrm{ml}$ sterile $0.1 \%$ peptone water, the contents were homogenized at Stomacher (M A 106402,France, 450 to 640 strokes per minute) for 2 minutes, the mixture was allowed to stand for 5 minutes at room temperature .The contents were transferred into sterile flask and thoroughly mixed by shaking and $1 \mathrm{ml}$ was transferred into separate tube each containing $9 \mathrm{ml}$ sterile $0.1 \%$ peptone water, from which tenth- fold serial dilutions were prepared. The prepared samples were subjected to the following bacteriological examination.

\subsection{Isolation and identification of E. coli (American Public Health Association "APHA", 1984).}


From the original dilution, one $\mathrm{ml}$ was inoculated into MacConkey broth tubes supplemented with inverted Durham's tubes. Inoculated tubes were incubated at $37^{\circ} \mathrm{C}$ for 24 hours. Enrichment broth: One $\mathrm{ml}$ from positive MacConkey tube was inoculated into another MacConkey broth tubes and incubated at $44^{\mathrm{D}} \mathrm{C}$ for 24 hours. Planting media: Loopfuls from positive MacConkey broth tubes were separately streaked onto plates of Eosin Methylene Blue agar medium (EMB), which were then incubated at $37^{\circ} \mathrm{C}$ for 24 hours. Identification of suspected E. coli isolates. Morphological identification according to Quinn et al. (2002). Motility test according to Quinn et al., (2002). Biochemical identification according to Quinn et al., (2002). Serological Identification: The isolates were serologically identified according to Kok et al. (1996) by using rapid diagnostic E. coli antisera sets (DENKA SEIKEN Co., Japan) for diagnosis of the Enteropathogenic types.

\subsection{Isolation and identification of Salmonellae (International Organization of Standardization "ISO", 2002)}

Pre-enrichment in non-selective broth: Twentyfive grams of examined samples were homogenized in $225 \mathrm{ml}$ of sterile buffered peptone water $(0.1 \%)$ in sterile blender jar and incubated at $37^{\circ} \mathrm{C}$ for 24 hours. Enrichment in selective broth: One $\mathrm{ml}$ of the inoculated Pre-enrichment culture was inoculated into $10 \mathrm{ml}$ Rappaport Vassilidis broth tube, then the tube was incubated at $43^{\circ} \mathrm{C}$ for 24 hours (Vassiliadis et al., 1978). Selective Plating: A loopful from selective enriched broth was streaked onto the surface of previously prepared Xylose lysine Desoxychoclate (XLD) agar and Brilliant Green agar. The plates were incubated at $37^{\circ} \mathrm{C}$ for 24 hours. Plates were examined for suspected Salmonella colonies which appeared as red with black centers on XLD agar and pink on Brilliant Green agar. Morphological identification according to Quinn et al., (2002). 3.2.5.5. Motility test: according to Quinn et al., (2002). Biochemical identification: The purified isolates of Salmonella were examined by different biochemical reactions according to Koneman et al. (1997) and Quinn et al., (2002).
Serological identification of Salmonellae: Isolates proved biochemically to be Salmonella microorganisms were subjected to serological identification according to Kauffman white scheme (Kauffman, 1974).

\section{RESULTS}

\subsection{Salmonellae in ready to eat sandwiches of beef Samples:}

The results recorded in tables (1) revealed that the incidences of Salmonellae. In the examined ready to eat samples were $32 \%, 60 \%, 8 \%, 40 \%$ for the examined sandwiches of beef products of kofta, liver, shawerma and sausage. Data in table (2) revealed that the serologically identified salmonella isolates in the examined samples of liver sandwiches were S. Typhimurium (20\%), S. Dublin (12\%) and S. Enteritidis (28\%), while in examined samples of kofta sandwiches S. Typhimurium (12\%), S. Enteritidis (8\%) and S. Haifa (12\%) were identified. Moreover, in the examined samples of beef shawerma sandwiches S. Typhimurium (4\%) and $S$. Enteritidis (4\%) were identified, moreover in the examined samples of sausage sandwiches were $S$. typhimurium (20\%) and S. Enteritidis (20\%) were identified.

\subsection{Escherichia coli in Ready to eat sandwiches of beef samples:}

The results recorded in tables (3) revealed that the incidence of $E$. coli in the examined ready to eat samples were $20 \%, 8 \%, 32 \%$ and $40 \%$ for sandwiches of kofta, shawerma, sausage and liver, respectively.

Table (1): Incidence of Salmonellae in the examined samples of ready to eat sandwiches of beef products

\begin{tabular}{lcc}
\hline Beef products & \multicolumn{2}{c}{ Positive samples } \\
& No & $\%$ \\
\hline Kofta & 8 & 32 \\
Liver & 15 & 60 \\
Shawerma & 2 & 8 \\
Sausage & 10 & 40 \\
Total & 25 & 25 \\
\hline
\end{tabular}

Table (2): Serotyping of Salmonellae isolated from the examined samples of ready to eat sandwiches of beef products $(\mathrm{n}=25)$.

\begin{tabular}{|c|c|c|c|c|c|c|c|c|c|c|}
\hline \multirow[t]{2}{*}{ Identified strains } & \multicolumn{2}{|c|}{ Kofta } & \multicolumn{2}{|c|}{ Liver } & \multicolumn{2}{|c|}{ Shawerma } & \multicolumn{2}{|c|}{ Sausage } & \multicolumn{2}{|c|}{ Total } \\
\hline & No & $\%$ & No & $\%$ & No & $\%$ & No & $\%$ & No & $\%$ \\
\hline S. Dubbin & - & - & 3 & 12 & - & - & - & - & 3 & 3 \\
\hline S. Haifa & 3 & 12 & - & - & - & - & - & - & 3 & 3 \\
\hline S. Enteritidis & 2 & 8 & 7 & 28 & 1 & 4 & 5 & 20 & 15 & 60 \\
\hline S. Typhimurium & 3 & 12 & 5 & 20 & 1 & 4 & 5 & 20 & 14 & 56 \\
\hline Total & 8 & 32 & 15 & 60 & 2 & 8 & 10 & 40 & 35 & 35 \\
\hline
\end{tabular}


Table (3): Incidence of Enteropathogenic E. coli in the examined ready to eat food samples.

\begin{tabular}{lccc}
\hline Products & No. of Samples & \multicolumn{2}{c}{ Positive samples } \\
& & No & $\%$ \\
\hline Kofta & 25 & 5 & 20 \\
Shawerma & 25 & 2 & 8 \\
Sausage & 25 & 8 & 32 \\
Liver & 25 & 10 & 40 \\
Total & 100 & 25 & 25 \\
\hline
\end{tabular}

\section{DISCUSSION}

The results recorded in tables (1) revealed that the incidences of Salmonellae. in the examined ready to eat samples were $32 \%, 60 \%, 8 \%, 40 \%$ for the examined sandwiches of beef products of kofta, liver, shawerma and sausage. The current results for kofta sandwiches were higher than those reported by Al-Mutairi (2011)) (0\%) and Al-Tawwab (2004) (4\%). Salmonellae were recovered from meat products by many investigators such as Abd El-Aziz (1987) (10\%), Ahmed (1988) (8\%), El-Mossalami et al. (1989) (6\%), El-Mossalami (2003) (5\%), Torky (2004) (5\%), and Siriken et al. (2006) (7\%).

Data in table (2) revealed that the serologically identified salmonella isolates in the examined samples of liver sandwiches were S. Typhimurium (20\%), S. Dublin (12\%) and S. Enteritidis (28\%), while in examined samples of kofta sandwiches S. Typhimurium (12\%), S. Enteritidis (8\%) and S. Haifa (12\%) were identified. Moreover, in the examined samples of beef shawerma sandwiches $S$. Typhimurium (4\%) and S. Enteritidis (4\%) were identified, moreover in the examined samples of sausage sandwiches were S. Typhimurium (20\%) and S. Enteritidis (20\%) were identified.

The presence of Salmonella spp. in cooked foods is often attributed to inadequate sanitation, poor personal hygiene during food handling, processing and storage, presence of waste close to food preparation and food premises, and inadequate refrigeration. Proliferation of this organism in foods may, therefore, result from handling cooked foods by workers who are carriers of Salmonella. Historically, S. Typhimurium has been the most frequent serotype and $S$. Enteritidis acts as a causative agent of human gastroenteritis throughout the world. An annual average of 186 cases was recorded during 1982-1986 in Norway (Sharma et al., 1996). Also S. Typhimurium is the commonest Salmonellae isolated from cases of food poisoning and represents about $50-60 \%$ of such cases (World Health Organization (WHO), 1967).

In Egypt S. Typhimurium was involved for several times in i food poisoning outbreaks due to consumption of meat and meat products (Ramadan and Sadek, 1971). Generally, the contamination of different meat products with Salmonellae may reflect insufficient hygienic measures.

The results recorded in tables (3) revealed that the incidence of $E$. coli in the examined ready to eat samples were $20 \%, 8 \%, 32 \%$ and $40 \%$ for sandwiches of kofta, shawerma, sausage and liver, respectively. E. coli was previously isolated by AlMutairi (2011); El-Mossalami (2003); El-Rayes (2008); El-Taher-Omyma (1998); Hassan (1991); Ibrahim-Ghada (2001); Soliman and El-Tabiy (2006) from the examined kofta samples, by AlMutairi (2011); El-Gohary (1993); Ibrahim-Ghada (2001); Vazgecer et al. (2004) from the examined sandwiches of beef shawerma samples. While the current results for the examined samples of koftasandwiches were higher than those obtained by Hassan (1991) (0\%) and lower than those obtained by Al-Tawwab (2004) (64\%), but similar to those obtained by El-Rayes (2008) (20\%), El-TaherOmyma (1998) ( 25\%), Al-Mutairi (2011) ( 28\%) and El-Mossalami (2003) (40\%). Moreover, the current results for the examined sandwiches of beef shawerma samples were lower than those obtained by Vazgecer et al. (2004) (31\%), Al-Mutairi (2011) (20\%), El-Gohary (1993) (78\%) and Al-Tawwab (2004) (48\%). The variation in the results may be due to the differences in manufacture practices, handling from producers to consumers and the effectiveness of hygienic measures applied during production. The presence of $E$. coli in food of animal origin is considered as indicator of faults during preparation, handling, storage or service (Tabbut, 1999). Although E. coli is readily killed by temperature above $55^{\circ} \mathrm{C}$, serious incidents occurred in such products, which reflect high level of abusing even to fecal contamination, cross contamination between raw foods and cooked one (Varnam and Evans, 1991). So, E. coli is considered as an indicator of fecal contamination, besides, it may induce severe diarrhea in infants and young children, as well as food poisoning and gastroenteritis among the adults (Synge, 2000). Detection or even low number of $E$. coli in foods constitutes a public health hazard as significant as the demonstration of Salmonellae (International Commission on Microbiological 
Specification for Foods "ICMSF", 1980). The pathogenic strains of $E$. coli associated with food borne illness were classified into 4 categories, Enteropathogenic E. coli (EPEC), Entero-invasive E. coli (EIEC), Enterotoxigenic E. coli (ETEC) and Enterohaemorrhagic E. coli (EHEC) (Doyle, 1990).

In general, EPEC strains are the major cause for many infantile diarrhea in typical cases, symptoms appear within 12 to 36 hours. Clinically, EPEC illness is characterized by fever, nausea, vomition and watery stools, which occasionally contain mucous, but without gross blood (Toledo et al., 1983). Furthermore, EPEC was implicated in cases of gastroenteritis, cystitis, colitis, pyelonephritis, peritonitis and puerperal sepsis as well as food poisoning outbreaks (Doyle, 1990). Therefore, EPEC showed to be the first bacterial cause of diarrhea in infants: and its proportion may reach 54\% (Varnam and Evans, 1991).

\section{REFERENCES}

Abd El-Aziz, A.T. 1987. Microbial load of some meat products as influenced by the hygienic status of the product plantM.V.Sc., Cairo University.

Ahmed, S. 1988. Salmonella in locally manufactured meat productsM.V.Sc., Cairo University, Egypt.

Al-Mutairi, M.F., 2011. The Incidence of Enterobacteriaceae Causing Food Poisoning in Some Meat Products. Adv. J. Food Science and Technol. 3, 116-121.

Al-Tawwab, M. 2004. Safety of street vended meat meals exposed to the open environmentM.V.Sc., Zagazig University.

American Public Health Association "APHA", 1984. Compendium of methods for the microbiological examination of foods, 2 nd ed. Speck, H.L, (ed) APHA, Washington D.C.

American Public Health Association (APHA), 1992. Compendium of methods for microbiological examination of Food, 3rd ed. Brothers, Ann, Arb.

Doyle, M.P., 1990. Pathogenic E.coli. The Lancet 336, 1111-1115.

El-Gohary, A.H., 1993. Sausage and minced meat as a source of food poisoning microorganisms to man. Assiut, Vet. Med. J. 30, 59.

El-Mossalami, E.E., Safwat, A.A.S., Abdel-Rahim, L., El-Sawah, H., 1989. Salmonella in locally produced meat products. J. Egypt. Vet. Med. Assoc. 49, 99-108.

El-Mossalami, E.K. 2003. Risk assessment of ready prepared meat products, , Thesis, , $\mathrm{PhD}$, Cairo Univ. Egypt.
El-Rayes, A.M.A. 2008. Incidence of pathogenic Escherichia colt in fast foodsM.V.SC., Benha University Egypt.

El-Taher-Omyma, M. 1998. Bacteriological quality of chicken meat productsM.V.Sc., Cairo University.

Fang, T.J., 2005. Bacterial contamination of readyto-eat foods: concern for human toxicity. Reviews in food and nutrition toxicity 4, 143 171.

Hassan, A.I. 1991. Sanitary improvement of passengers meals in air catering plantPhD, Cairo University.

Ibrahim-Ghada, M.M. 2001. Ready-to-eat sandwiches as a source of Potential PathogenM.V.Sc., Assiut University.

International Organization of Standardization "ISO", 2002. International Organization for Standardization. No.6579. Microbiology of Food and Animal Feeding Stuffs. Horizontal Methods for detection of Salmonella species.

International Commission on Microbiological Specification for Foods "ICMSF", 1980. Microbiological ecology of foods. Vol. I. Factors affecting life and death of microorganisms. Academic Press, New York, London, Sydney.

Kauffman, G., 1974. Kauffmann white scheme. J. Acta. Path.Microbiol. Sci. 61, 385.

Kok, T., Worswich, D., Gowans, E., 1996. Some serological techniques for microbial and viral infections. In Practical Medical Microbiology (Collee, J.; Fraser, A.; Marmion, B. and Simmons, A., eds.), 14th ed. Edinburgh, Churchill Livingstone, UK.

Koneman, E., Allen, S., Janda, W., Sehreckenberger, C., Winn, W., 1997. Color Atlas and text book of Diagnostic Microbiology, Fifth ed. Lipp in cott, Philadelphia, New York.

Mosupy, F.M., Arntzen, L., Van Holy, A., 1998. Microbiological survey of street-vended food in the Johannesburg metropolitan area of South Africa. Food Sci 63, 842 - 846.

Quinn, p., Markey, B., Carter, M., Donelly, W., Leonard, F., 2002. Veterinary Microbiology and Microbial Disease. Black Well Science.

Ramadan, K., Sadek, L., 1971. Parameters of Salmonellosis in Egypt. Vet. Med. Ass. 31, 193- 218.

Sharma, D., Sharma, V., Kuraar, A., 1996. Microbial quality of commercial pork products. Int. J. Animal Sci. 66, 211- 213.

Siriken, B., Pamuk, S., Ozaku, C., Gedikoghe, S., Eyigor, M., 2006. A note on the incidences of Salmonella species, Listeria species and Escherichia coli O157:H7 serotypes in 
Turkish sausage (soudjouck). Meat Sci. 72, 713.

Soliman, Z.I., El-Tabiy, A.A., 2006. A study on the occurrence of Escherichia. coliin some beef products with special reference to E. coli O157: H7. Assuit- Vet. Med. J. 52, 75-87.

Synge, B.A., 2000. Verocytotoxin producing E. Coli, a. veterinary review. J. Appl. Microbiol. 88, 315-375.

Tabbut, G.M., 1999. Comparative study of visual inspections and microbiological sampling in premises manufacturing and selling high risk foods. Epidemiol. Infect. 103, 775-786.

Toledo, M.R.F., lvariza, M.C.B., Murahovschi, J., Sramos, S.R.T., Trabulsi, L.R., 1983. EnteropathogenicEscherichia coli serotypes and endemic diarrhea in infants. Infec. Imrnun. 39, 586-589.

Torky, A.A.S. 2004. Trials for inhibition of some food poisoning microorganisms in meat productsPhD, Cairo University.
Varnam, A.H., Evans, M.G., 1991. Food borne pathogens. An illustrated text chapter 13. Wolfe publishing Ltd., England.

Vassiliadis, P., Trichopoulos, D., Pateraki, K., papaicoroman, N., 1978. Isolation of Salmonella from minced meat by the use of a new procedure of enrichement., Zbl. Bakt. Parasiten and InfektionShrankheiten and Hygiene 166, 81.

Vazgecer, B., Ula, B., Oztan, A., 2004. Microbiological and chemical qualities of chicken doner kebab retailed on the Turkish restaurants. Food Control 15, 261-264.

World Health Organization "WHO", 1984. The role of food safety in health development, Report of Joint FAO/WHO Expert Committee on Food Safety, Geneva.

World Health Organization (WHO), 1967. Third report of the joint FAO/WHO Tech. Rep. Exp. Committee on Zoonoses. WHO Tech. Rep. Ser. No. 378. 